\title{
Studi Kualitatif Pertumbuhan Populasi Kambing Paket Bantuan Crash Program dan Faktor yang Mempengaruhinya: Studi Kasus di Kampung Sekendi Distrik Teminabuan Kabupaten Sorong Selatan
}

\author{
Thimotius Sraun \\ Fakultas Peternakan Perikanan dan Ilmu Keluatan, Universitas Negeri Papua \\ Jl. Gunung Salju, Amban, Manokwari 98314, Papua Barat-Inonesia \\ E-mail: thimotiussraun@yahoo.com
}

\begin{abstract}
ABSTRAK
Distribusi paket bantuan kambing lokal merupakan objek/substansi implementasi kebijakan Crash program pada tahun 1995, dengan 8 anggota masyarakat kampung Sekendi Distrik Teminabuan Kabupaten Sorong Selatan sebagai "target group“. Pelaksanaan kebijakan/ program bertujuan meningkatkan populasi kambing sebagai objek dan populasi ternak sebagai subyek/partisipan. Penelitian ini bertujuan mengetahui pertumbuhan populasi ternak dan populasi peternak dan faktorfaktor yang mempengaruhinya. Hasil penelitian menunjukkan bahwa pertumbuhan/perkembangan populasi kambing bersifat negatif dengan penurunan populasi ternak dan peternak berturut-turut sebesar 73,68\% dan 66, 67\%. Ketidaksiapan sosial - ekonomi, aspek teknik pakan, reproduksi dan tatalaksana merupakan faktor - faktor yang mempengaruhi pertumbuhan populasi kambing tersebut. Distribusi paket bantuan kambing kebijakan "crash Program"gagal mencapai tujuan karena kesalahan dalam proses implementasinya.
\end{abstract}

Kata kunci: populasi kambing, faktor sosial - ekonomi, crash program, kambing

\section{Qualitative Study of Goat Population Growth of Crash Program and Affecting Factors: A Case Study in Kampung Sekendi Teminabuan District, Sorong Selatan}

\begin{abstract}
Distribution of crash program-based local goat constitutes an object of agriculture policy of crash program implemented in 1995, and has done using members of Sekendi community village at district of Teminabuan of Sorong Selatan regency as targeted group. The program aimed to increase population of goat as the goal and the population of goat as subject. Village of Sekendi was chosen as visited sites. The finding of this research shown that population growth of goat is declining where the population of goat and goat farmers are decreasing at $73.68 \%$ and $66,67 \%$, respectively. Uncertainty of socio-economic and feeding ration, reproduction and management are factors determining population growth of goat. The failure of crash program based-goat is failed to achieve the goal.
\end{abstract}

Key words: goat population, socio-economical factors, crash program, goat 


\section{PENDAHULUAN}

Kambing merupakan salah satu komoditi ternak ruminansia kecil, yang telah terbukti dapat memberikan manfaat ganda bagi masyarakat petani peternak. Kambing tergolong ternak yang memiliki tipe kelahiran lebih dari satu anak (antara 2-3 ekor) per kelahiran, dengan frekuensi beranak 2 kali dalam satu tahun, mempunyai produk sampingan berupa feces yang dapat dijadikan rabuk, bulu dan tanduk untuk dijadikan bahan baku industri kerajinan, tepung tulang dan tepung darah sebagai bahan penyusuun ransum, merupakan tabungan yang sewaktu - waktu dapat diuangkan dan efisien dalam pemanfaatan sumberdaya imput (sarana produksi). Dengan demikian kambing memiliki nilai ekonomi yang relatif mengutungkan petani peternak. Selain member manfaat ekonomi, kambing juga daapt memberikan manfaat social yang luas dan ini lebih berkaitan dengan adat istiadat dan agama yang hidup berdapingan komunitas social di papua. Artinya, usaha peternakan kambing tidak terkaendala dengan adat istiadat dan agama yang dianut oleh masyarakat, sehingga penyebaran (kemanfaatan) dan aspek pemasaran menjadi lebih luas. Karena produk kambing berupa daging semakin banyak dibutuhkan luas untuk kepentingan upacara adat atau digunakan untuk keperluaan perhelatan pesta-pesta dan kepentingan lainya. Kebutuhan ini harus meningkat terkait semakin meningkatnya jumlah dan keragaman poplasi penduduk diberbagai kota di Papua.

Manfaat ganda yang dimiliki kambing telah mendorong dimanfaatkan komoditi ternak tersebut sebagai substasi (paket batuan) dalam implementasi kebijakan Crash Program pada tahun 1995. Paket bantuan kambing itu didistribusikan ke berbagai komunitas social di Papua, yang menjadi kelompok sasaran (target group) khususnya masyarakat kampung Sekendi Distrik Teminabuan Kabupaten Sorong (sekarang kabupaten Sorong Selan). Paket bantuan itu diberikan dengan rasio sex $17: 2$ atau dengan jumlah populasi awal 19 ekor kepada “ target group " yang terdiri dari 8 orang kepala keluarga (KK). Paket bantuan diberian dengaan tujuan untuk meningkatkan populasi ternak sebagai subyek implementasi kebijakan tersebut. Pada gilirannya diharapkan dapat berdampak transformasi sosio-ekonomi (kesejahteraan sosial-ekonomi yang meningkat) pada masyarakat yang menjadi "target group". Namun hingga sekarang belum diketahui sampai sejauh mana perkembangan populasi kambing yang menjadi obyek (substansi) implementasi kebijakan Crash Program di kampung Sekendi berkaitan dengan itu, suatu penelitian bertujuan untuk mengetahui pertumbuhan dan perkembangan populasi kambing tersebut, faktor - faktor yang mempengaruhinya dan bagaimana proses implementasi kebijakan tersebut.

\section{MATERI DAN METODE}

Penelitian dilakukan di Kampung Sekendi Distrik Teminabuan Kabupaten Sorong Selatan yang merupakan kabupaten pemekaran dari kabupaten Sorong. Kampung Sekendi merupakan salah satu dari 18 kampung di Distrik Teminabuan terletak di bagian utara kota Teminabuan yang menjadi ibu kota baik Distrik Teminabuan maupun Kabupaten Sorong Selatan, terletak pada jarak $\pm 2-3 \mathrm{~km}$ dari kantor Distrik dan Bupati, secara astrologis terletak pada koordinat $130{ }^{\circ} 42^{\prime} 0$ '’BT dan $2^{\circ} 17^{\prime} 24^{\prime \prime}$ LS. Dapat ditempuh dengan berjalan kaki dan kendaran beroda dua.

Penelitian ini dilakukan pada tanggal 17 - 18 Desember 2008 dan materi penelian adalah ternak dan peternakan/anggota masyarakat yang menjadi “ target group ".Penelitian ini mengunakan metode deskritif dengan pendekatan kualitatif observatif, mengguanakan teknik wawancara mendalam tidak terstruktur terhadap informan kunci (key informan) yang ditetapkan secara sengaja (purposive). Personil yang menjadi informan kunci dalam penelitian ini adalah kepala kampung, tokoh pemuda dan aparat penyuluh serta anggota 
masyarakat sebanyak 2 orang sebagai repressentase dari target group (penerima paket bantuan). Untuk validasi informasi dilakukan cross-check ke semua pihak menjadi informan kunci.

\section{HASIL DAN PEMBAHASAN}

\section{Populasi Kambing dan Peternak}

Hasil penelitian tentang jumlah awal dan akhir populasi kambing dan peternak/anggota masyarakat yang menjadi "target group" (penerimaan paket bantuan dari implementasi kebijakan Crash Program) disajikan pada Tabel 1.

Dari Tabel 1 terlihat bahwa jumlah awal populasi kambing dan peternak (penerima bantuan), masing - masing sebanyak 19 ekor dan 9 orang. Sementara jumlah akhir populasi kambing dan peternak, masing - masing adalah 5 ekor dan 3 orang, atau telah terjadi penurunan jumlah populasi kambing sebesar 14 ekor (73,68 \%) dan peternak sebesar 6 orang $(66,67 \%)$. Data ini menujukkan bahwa baik populasi kambing maupun peternak mengalami pertumbuhan yang bersifat negatif dengan degradasi populasi pada ternak dan peternak. Dengan demikian, tujuan implementasi kebijakan Crash Program melalui distribusi paet bantuan tersebut tidak tercapai. Kegagalan ini diduga disebabkan berbagai faktor sosial-ekonomi dan faktor teknis (pakan, reproduksi dan tatalaksana).

\section{Ketidaksiapan Sosial - Ekonomi}

Sifat pertumbuhan/perkembangan populasi baik ternak maupun peternak sebagaimana telah dibahas diatas diduga lebih dilikian isebabkan oleh ketidaksiapan social-ekonomi masyarakat yang menjadi "target group“. Ketidaksiapan mereka dilihat dalam konteks latarbelakang pendidikan, kepemilikan sumberdaya ekonomi/sarana produksi dan keterlibatan mereka dalam tahapan proses kebijakan tersebut. Sifat pendekatan implementasi kebijakan Crash Program adalah “top down " dan sentralistik sehingga tidak mempertimbangkan latar belakang target group/partisipan yang umumnya tidak berpendidikan dan memiliki keterbatasan dalam hal kepemilikan sarana produksi/modal usaha. Tingkat pendidikan mempengaruhi daya respon untuk berinovasi dan hal ini berawal dari keterbatasan secara ekonomi. Berdasarkan bukti empiris observasi Semaoen (1997) yang menggunakan data Susenas (1992 dan 1993) sampai pada kesimpulan bahwa ada kecenderungan rumah tangga miskin akan selalu tertinggal dalam “ investasi “ sumberdaya kesejahteraannya.

Terkait keterbatasan pendidikan "target group", Mosher (1995) menyatakan juga bahwa kemampuan petani dan keputusan - keputubesan yang di ambilnya mengenai pelaksanaan usahatani, begitu menentukan bagi tingkat kecepatan pembangunan pertanian, maka program khusus untuk pendidikan petani merupakan segi penting dari pendidikan untuk pembangunan.

Pertumbuhan populasi yang demikian merupakan konsekuensi logis dari kebijakan Crash Program yang bersifat "top down" dan "sentralistik". Dari analisis Rian (2004) diketahui bahwa model "top down" mudahnya berupa pola yang dikerjakan oleh pemerintah untuk rakyat, partisipasi masyarakat lebih berbentuk mobilisasi. Selain itu, berdasarkan analisis Wibawa (1994) tentang model elite yang memiliki kemiripan dengan analisis Rian (2004) dalam formulasi kebijakan, yang mengacu pada Dye, juga diketahu bahwa elite secara "top down" memformulasikan kebijakan public untuk diimplementasikan oleh administrator public (implementor) pada rakyat banyak.

Dari pendapatan para teoritis kebijakan public itu, diketahui bahwa tahapan proses kebijakan dengan model "top down" tidak mengikutsertakan partisipasi masyarakat dan lebih diorientasikan pada kepentingan (interest). Kebijakan public yang didominasi kepentingan pada hakekatnya tidak mempertimbangkan kesiapan masyarakat 
Tabel 1. Jumlah awal dan akhir Populasi Kambing dan Peternak Bantuan Crash Program di Kampung Sekendi Distrik Teminabuan Tahun 2008.

\begin{tabular}{cccc}
\hline \multirow{2}{*}{ Jenis Populasi } & \multicolumn{2}{c}{ Uraian Perkembangan Populasi } & \multirow{2}{*}{$\begin{array}{c}\text { Nisbah } \\
\text { (\%) }\end{array}$} \\
\cline { 2 - 3 } & Awal (1995)/Ekor & Akhir (2008)/Ekor & \\
\hline Kambing & 19 & 5 & 26,31 \\
Peternak & 9 & 3 & 33,33 \\
\hline
\end{tabular}

Sumber : Data Primer, 2008.

lokal yang menjadi “target group”. Hal ini merupakan kesalahan dalam implementasi yang menjadi "sebab gagalnya kebijakan pemerintah untuk sebagian besar harus dicapai dalam pelaksanaan”.

Kegagalan pelaksanaan kebijakan Crash Program di lokasi penelitian yang diindikasikan tujuan kebijakan yang tidak tercapai, disebabkan kerena berbagai kesalahan, satu diantaranya adalah kelalaian mengkomunikasikan (informasi) sejak dini melalui sosialisasi. Sosisalisasi dilakukan untuk menyampaikan substansi dan tujuan kebijakan sehingga target group memiliki kesiapan berpartisipasi memungkinkan distribusi substansi kebijakan menjadi tepat waktu, tepat sasaran, tepat jumlah dan tepat mekanisme. Seorang informan kunci menyatakan bahwa pelaksanaan kebijakan Crash Program dalam bentuk paket bantuan ternak kambing, ke Kampung Sekendi tidak disosialisasikan ("kami tiba - tiba diserahkan bantuan kambing, tidak ada informasi awal"). Sementara menurut para teoritis kebijakan, seperti Eduards III (1980), "efektifitas implementasi kebijakan mensyaratkan pengetahuan yang memadai dari para pelaksana keputusan kebijakan (implementer dan target group) tentang apa yang harus mereka lakukan. Semakin cermat keputusan dan perintah kebijakan dikomunikasikan kepada mereka yang harus dilaksanakan, sementara menurut Bordenave dalam Rogers (1985) bahwa "komunikasi masih tetap dianggap sebagai perpanjangan tangan para pembuat kebijakan (perencanaan pembangunan) dan fungsi utamanya adalah untuk mendapatkan dukungan masyarakat dan partisipasi mereka dalam implementasi kebijakan pembangunan”.

\section{Faktor - Faktor Teknis}

\section{Reproduksi (breeding)}

Hasil penelitian tentang tipe kelahiran sebagai salah satu aspek yang relavan dengan proses reproduksi (breeding) kambing di kampung Sekendi disajikan pada Tabel 2.

Tabel 2 menunjukkan bahwa kambing yang merupakan paket bantuan kebijakan Crash Program, 10 ekor (52,63 \%) diantaranya memiliki tipe kelahiran 0,4 ekor $(21,05)$ dengan tipe kelahiran 1 dan 5 ekor (26,32 \%) dengan tipe kelahiran lebih dari 1 ekor per kelahiran (2-3 ekor). Menurut informan kunci, "10 ekor kambing dengan tipe kelahiran 0 tidak pernah menunjukkan tanda - tanda bunting selama 2 tahun”, sehingga keputusan yang diambil peternak adalah menjual sejumlah kambing tersebut. Sementara kambing dengan jumlah anak baik 1 ekor maupun lebih dari 1 ekor per kelahiran”, kondisi anaknya ada yang kurang sehat sehingga dengan mudah dimangsa hewan (anjing dan babi). Keadaan reproduksi yang demikian ikut mempengaruhi perkembangan populasi kambing di Kampung Sekendi sebagaimana telah dibahas pada bagian sebelumnya.

\section{Pakan (Feeding)}

Gangguan pada reproduksi kambing di Kampung Sekendi diduga berkaitan dengan pengaruh faktor pakan (feeding). Pakan utama kambing sebagai salah satu ternak ruminansia adalah hijauan yang terdiri dari rumput, leguminosa dan dedaunan berbagai pohon dan limbah pertanian. Hasil penelitian dengan pendekatan kualitatif - observatif ini 
Tabel 2. Tipe Kelahiran Kambing Paket Bantuan Kebijakan Crash Program Di Kampung Sekendi Distrik Teminabuan Tahun 2008.

\begin{tabular}{ccc}
\hline $\begin{array}{c}\text { Tipe Kelahiran } \\
\text { (Jumlah ekor/kelahiran) }\end{array}$ & $\begin{array}{c}\text { Jumlah Kambing/Ternak } \\
\text { (Ekor) }\end{array}$ & Nisbah \\
\hline 0 & 10 & 52,63 \\
1 & 4 & 21,05 \\
$>1$ & 5 & 26,32 \\
\hline
\end{tabular}

Sumber : Data Primer, 2008

menunjukan bahwa Kampung Sekendi terletak di daerah berbukit batu yang agak terjal. Topografi lahan tidak mendukung penutupan lahan (covering) secara merata oleh vegetasi rumput alam dengan komposisi botanis yang tidak beragam.

Kondisi itu berdampak tidak tersedia pakan hijauan yang memenuhi syarat kualitas, kuantitas dan kontinuitas bagi ternak. Faktor lingkungan, yang salah satunya adalah ketersedian hijauan pakan yang memenuhi syarat kualitas dan tersedia sepanjang waktu memberi pengaruh sebesar $70 \%$ terhadap produktivitas ternak ruminansia. Monika et al. (1993) telah berhasil membuktikan melalui penelitian yang dilakukan bahwa performan/tampilan ternak kambing betina terutama selama masa perkawinan dipengaruhi faktor ketersedian hijauan makanan ternak tersedia dibawah kebutuhan dasar baik secara kualitas maupun kuantitasnya. Pada kambing jantan kekurangan hijauan makan ternak yang terlampau banyak mengurangi volume testis dan (perkembangan) secara umum pada kambing. Pada kambing betina ukuran dari respon reproduksi (perilaku reproduksi kambing betina) terhadap makanan ternak dapat dinyatakan dengan tingkat keberhasilan perkawinan, banyaknya anak per kelahiran (tipe kelahiran), kemampuan hidup anak dan tenggang waktu antara perkawinan.

Berkaitan dengan pendapat Siregar serta Monika et al. (1993), dapat dinyatakan bahwa kegagalan reproduksi kambing di lokasi penelitian lebih disebabkan karena ketersediaan hijauan pakan yang tidak mendukung. Letak Kampung Sekendi di daerah berbukit batu yang agak terjal, dikelilingi vegetasi hutan, berakibat tidak tersedianya area yang menjadi sumber hijauan pakan konvensional, untuk mendukung ritme proses reproduksi yang efisens. Bearden et al. (2004) menunjukkan bahwa terdapat efek nutrisional terhadap proses reproduksi pada hewan ternak, khususnya ternak ruminansia. Komoditi ternak tersebut memerlukan asupan nutrisi yang berimbang guna menunjang proses reproduksi yang normal. Faktor nutrisional (pakan) yang diperlukan untuk mendukung keberhasilan proses reproduksi sama pentingnya dengan kebutuhan nutrisi untuk hidup pokok/perawatan (maintenance), pertumbuhan (growth) dan laktasi (lactation). Menurut Bearden et al. (2004), keterbatasan pengetahuan para anggota "target group" tentang dominasi pengaruh nutrisi pakan terhadap produksi dan reproduksi ternak yang efisien,berakibat gangguan pada proses reproduksi. Hal ini berakibat pertumbuhan/ perkembangan populasi kambing yang "bersifat negatif sebagaimana telah dijelaskan dalam bagian sebelumnya. Keterbatasan "target group" dalam aspek tersebut berawal dari kebuntuan informasi teknologi budidaya ternak kambing akibat tidak berperanya aparatur penyuluh seperti dikemukakan key informan "kami tidak pernah mendapat penyuluhan tentang hal itu” (peranan hijauan pakan). Kebuntuan ini menurut hemat penulis, wajar saja terjadi karena implementasi kebijakan tersebut.,menurut informan dari instansi teknis terkait: "tidak dilaksanakan secara terkoordinasi”. Selain itu, faktor kompleksitas geografis dan keterbatasan 
aksesbilitas serta sumberdaya aparatur ketika kebijakan ini diimplementasikan juga berimplikasi pada kebuntuan informasi teknologi tersebut.

\section{Tatalaksana (Managemet)}

Dalam tulisan ini, tatalaksana menyakut kegiatan perawatan kambing dan berbagai aspek teknis terkait, yang mempersyaratkan penyedian kandang yang memenuhi syarat minimal sebuah kandang yang baik. Hasil penelitian, menujukkan bahwa seorangpun dari anggota "target group" implementasi kebijakan Crash Program di Kampung Sekendi memiliki kandang kambing. Sementara kandang mempunyai fungsi penting untuk melindungi ternak dari ganguan/pengaruh faktor iklim dan biologis (pemangsa dan penyakit) serta untuk memudahkan penanganan dan perawatan ternak.

Hal ini selain disebabkan paket bantuan kambing yang tidak menyertakan biaya pengadaan/pembuatan kandang, juga akibat kebuntuan informasi teknologi sebagaimana telah dijalaskan sebalumnya. Ketidakpemilikan kandang merupakan slah satu penyebab terjadinya degradasi populasi kambing dengan pertumbuhan yang bersifat negatif dalam pembahasan sebelumnya telah dikemukakan bahwa pemangsaan anak kambing (dimakan/digigit anjing dan babi) merupakan satu diantara beberapa penyebab mundurnya populasi kambing di lokasi penelitian. Pemangsaan berpeluang terjadi karena kambing tidak dikandangkan dan ini merupakan bagian dari kesalahan implementasi kebijakan tersebut.

\section{KESIMPULAN DAN SARAN}

\section{Kesimpulan}

Berdasarkan hasil penelitian dapat disimpulkan beberapa hal yang relevan dengan tujuan penelitian sebagai berikut :

1. Populasi kambing dan peternak sebagai substansi implementasi kebijakan Crash Program di Kampung Sekendi mengalami degradasi dengan trend pertumbuhan popilasi yang bersifat negative. Artinya, kebijakan tersebut telah gagal dilaksanakan di Kampung Sekendi.

2. Ketidaksiapan sosial-ekonomi dan faktor teknis yang mencangkup pakan, reproduksi/ pemuliabiakan, dan tatalaksana berpengaruh terhadap pertumbuhan populasi kambing yang bersifat negatif di Kampung Sekendi.

3. Penyebab kegagalan mencapai tujuan adalah kesalahan yang terjadi dalam proses implementasinya.

\section{Saran}

Implementasi sebuah kebijakan pembangunan, seyogyanya diawali dengan tahapan proses mempersiapkan masyarakat yang menjadi "target group". Untuk itu pendekatan yang bersifat "bottom up" perlu dikedepankan dalam rangka mengikutsertakan partisipasi masyarakat secara sadar (inner power).

\section{DAFTAR PUSTAKA}

Bearden, H.J, Fuquay,J.W. and Williard, S.T. 2004. Applied Animal Reproduction. Pearson Prentice Hall.

Eduards III, G. E. 1980. Implementing Public Policy. Washington DC Congressional Quartierly Persada. Jakarta.

Fadilla, P. 2000. Paradigma kritis pembuatan kebijakan publik. PT. Raja Grafindo Persada. Jakarta.

Monika, Wodzicka-Tornaszewska, I.M.Mastika, A. Djajanegara, Susan G. 1993. Peterjemah : I. Made Mastika, Komang Gede Suryana, I Gusti Lanay Oka dan Ida Bagus Sustrisna. Produksi Kambing dan Domba di Indonesia. Sebelas Maret. University Press. Surakarta.

Rian, N. D. 2003. Kebijakan Publik. Formulasi, implementasi dan Evaluasi.PT. Alex Media Komputindo. Kelompok Gramedia. Jakarta.

Rotqers, H. R. 1972. Law and Social Change. New York. McGraw Hill.

Wibawa, S. 1994. Evaluasi Kebijakan Publik. PT. Raja Grafindo Persada. Jakarta. 